\title{
Copper and Molybdenum Uptake by Forages Grown on Coal Mine Soils
}

\author{
DENNIS R. NEUMAN AND FRANK F. MUNSHOWER
}

\begin{abstract}
Coal mine soils have shown a tendency to produce leguminous vegetation containing elevated concentrations of molybdenum (Mo). The potential for cattle developing copper $(\mathrm{Cu})$ deficiency by grazing vegetated areas is increased at one mine where a shale interburden material contains elevated Mo levels. The purpose of this study was to determine if mixing or dilution of the interburden with low-Mo sandy overburden would produce vegetation with undesirably high Mo levels or low $\mathrm{Cu} / \mathrm{Mo}$ ratios.

Concentrations of $\mathrm{Cu}, \mathrm{Mo}$, sulfur, and $\mathrm{Cu} / \mathrm{Mo}$ ratios of several legumes and one grass species grown on these alkaline coal mine soils suggest that, with the exception of white sweetclover, mixing of the Mo-bearing interburden material with sandy overburden resulted in desirable elemental levels and ratios for grazing cattle if the mine soils were covered with an adequate depth $(0.6 \mathrm{~m})$ of suitable topsoil. Vegetation uptake of Mo was species and site specific.
\end{abstract}

In 1976, an investigation of copper ( $\mathrm{Cu}$ ) and molybdenum (Mo) levels in 2 leguminous species, yellow and white sweetclover (Melilotus officinalis and $M$. alba), grown on revegetated mine soils of the Northern Great Plains was initiated by Erdman and his coworkers (1978). They reported a $\mathrm{Cu} / \mathrm{Mo}$ ratio of 0.44 and a Mo level of $13 \mu \mathrm{g} / \mathrm{g}$ for white sweetclover collected at the Big Sky Mine in southeastern Montana and concluded that cattle grazing predominantly on this vegetation could display subclinical or acute symptoms of molybdenosis. Legumes growing on revegetated mine areas have exhibited a tendency to accumulate higher concentrations of Mo than those growing on native range or cultivated fields (Munshower and Neuman 1978a). As a complicating factor the $\mathrm{Cu}$ content of vegetation on the Northern Great Plains in southeastern Montana is generally marginal in terms of required cattle nutritional needs. This low Cu status is common to both native range vegetation and established plants on revegetated coal

Authors are associate research chemist and director and associate research plant ecologist at the Reclamation and Research Unit, respectively, Montana Agricultural Experiment Station, Department of Animal and Range Sciences, Montana State Lniversity, Bozeman 59717

This contribution was submitted as Montana Agricultural Experiment Station Journal Series No. 1413. This work was supported entirely by the Peabody Coal Company, Denver, Colo. mine soils (Munshower and Neuman 1978b and 1980).

At the Big Sky Mine the possibility of elevated plant available Mo in spoil material is increased by the high levels of extractable Mo ( 1 to $4 \mu \mathrm{g} \mathrm{Mo} / \mathrm{g}$ ) in the blue-grey shale interburden material located between the Rosebud and McKay coal seams. The mining company has been required to selectively handle the shale and bury it below $2.4 \mathrm{~m}$ of sand y overburden in the reclamation process. The ultimate goal of this study was to determine if mixing or dilution of the shale interburden with sandy overburden would produce vegetation with undesirably high Mo levels or low $\mathrm{Cu} / \mathrm{Mo}$ ratios. A corollary to this goal was the investigation of the impact of topsoiling on these plant Mo concentrations and $\mathrm{Cu} / \mathrm{Mo}$ ratios.

Leguminous plants are known to be accumulators of Mo. This element is an integral part of the nitrogenase enzyme system responsible for the reduction of atmospheric nitrogen to ammonia and hence is important to the symbiotic bacteria in root nodules of nitrogen-fixing legumes.

Although elevated levels of Mo in vegetation are not injurious to the plants themselves, animals are very sensitive to high Mo levels. The required dietary level for grazing cattle and sheep is small and concentrations in the total diet as low as $5 \mu \mathrm{g} \mathrm{Mo/g}$ may be toxic under certain conditions (Webb and Atkinson 1965). Dietary levels of $10-20 \mu \mathrm{g} / \mathrm{g}$ are nearly always associated with disturbed $\mathrm{Cu}$ metabolism because of the antagonistic action of these elements (Allaway 1977). The ratio of these 2 elements in vegetation is of prime concern when discussing the potential for induced $\mathrm{Cu}$ deficiency in grazing animals. $\mathrm{A} \mathrm{Cu} / \mathrm{Mo}$ ratio of 2.0 is considered the lowest acceptable value in ruminant feeds (Miltmore and Mason 1971).

The sulfur (S) intake of the ruminant animal exerts a significant influence on the $\mathrm{Cu}-\mathrm{Mo}$ interrelationship (Suttle 1975). Ingested Mo plus $\mathrm{S}$ can either increase or decrease the absorption of $\mathrm{Cu}$, depending on their ingestion relative to $\mathrm{Cu}$ (Underwood 1977). Suggested dietary intake of $\mathbf{S}$ is $0.1 \%$ for beef cattle (National Research Council 1976) and $0.2 \%$ for dairy cattle (National Research Council 1971).

High Mo forages that may be toxic to grazing animals in the spring have been shown to lose their toxicity when cut as hay or when dry and cured in the field (Ferguson et al. 1943). However, Barshad (1948) reported large increases in Mo concentrations for several plants as they aged. Furthermore, a seasonal decrease in the 
$\mathrm{Cu}$ content of native grasses has been reported (Munshower and Neuman 1978b).

\section{Methods and Materials}

\section{Site Selection}

The Big Sky Mine, owned and operated by Peabody Coal Co., is located in Rosebud County 5 miles south of Colstrip, Mont. Four study sites were established at this mine. Site 1 consisted of old mine spoils of mixed interburden and overburden devoid of any topsoil. Site 2 was mixed interburden and overburden covered with $0.6 \mathrm{~m}$ of topsoil. At Site 3 the mixed interburden and overburden was buried below $2.4 \mathrm{~m}$ of overburden material and $0.6 \mathrm{~m}$ of topsoil. An undisturbed, native range site was used as a control plot.

\section{Plot Design and Seeded Species}

Yellow sweetcover (Melilotus officinalis Lam.), white sweetclover (M. alba Desr.), alfalfa (Medicago sativa $\mathbf{L}$.), white prairieclover (Petalostemon candidum Michx.), purple prairieclover ( $P$. purpurem Rydb.), cicer milkvetch (Astragalus cicer L.) and green needlegrass (Stipa viridula Trin.) were seeded in $1.2 \times 1.5-\mathrm{m}$ plots that were replicated $3 x$ at each of the 4 study sites in fall 1980 . Straw mulch was used as an amendment except on the native range site where native vegetation provided a natural mulch. Germination and emergence of most species were complete in spring 1981.

\section{Soil Determinations}

Soils were collected on 2 occasions, at vegetation seeding (fall 1980) and in fall 1981. Soil cores were augered at the corners of each study site and the surface, $20,40,80$, and $120 \mathrm{~cm}$ fractions were air-dried and gently crushed to pass a $2-\mathrm{mm}$ sieve. Several physical and chemical determinations were made including $\mathbf{p H}$ of the saturated soil paste, DTPA extractable $\mathrm{Cu}$, and ammonium oxalate extractable Mo.

\section{Vegetation Determinations}

Several grams of vegetation were collected from each plot at each site on 4 occasions: after 1 growing season in September 1981 , and on June 1, July 14 and September 9, 1982. Short plants were clipped approximately $5 \mathrm{~cm}$ above ground level to avoid soil contamination, while only the top $22 \mathrm{~cm}$ of taller plants, sweetclovers and alfalfa, were collected. The vegetation was oven dried, ground to pass a 40-mesh screen and analyzed for $\mathrm{Cu}$ and $\mathrm{Mo}$ concentrations by electrothermal atomic absorption spectroscopy (AAS) after acid digestion (Neuman and Munshower 1981). Total $\mathrm{S}$ concentration was indirectly determined by analysis of excess barium (Ba) by flame AAS after formation of insoluble barium sulfate in the dissolved ash of plant samples (Horwitz 1975).

\section{Results and Discussion}

The question of burial of the Mo bearing interburden material or dilution with sandy overburden may be resolved by examining the following: plant available $\mathrm{Cu}$ and Mo within the root zone; vegetation $\mathrm{Mo}, \mathrm{Cu}$, and $\mathrm{S}$ concentrations; and the subsequent $\mathrm{Cu} / \mathrm{Mo}$ ratios.

\section{Copper and Molybdenum in Soils}

Soil $\mathrm{pH}$ is one of the most important single factors affecting the uptake of $\mathrm{Mo}$ and $\mathrm{Cu}$ in plants. In this study the soil $\mathrm{pH}$ levels ranged from 7.0 to 7.9 with little intersite variation. Molybdenum is readily available to vegetation in this $\mathrm{pH}$ range and $\mathrm{Cu}$ less available. The concentrations of extractable Mo in the study site soils are shown in Table 1 with the data arranged by soil profile depth. The overall mean extractable Mo level for each site is also given. Non-topsoiled mine soils from Site 1 exhibited the highest overall mean level of $0.46 \mu \mathrm{g} \mathrm{Mo} / \mathrm{g}$. Of the topsoiled study sites, Site 3 (segregated interburden) and Site 2 (mixed interburden) revealed similar extractable Mo concentrations. However, when intersite variation by profile depth was evaluated, Site 3 contained higher $(p \leq 0.05)$ extractable Mo at the $80-\mathrm{cm}$ level than soils from Site 2. Both of these sites exhibited elevated Mo at the lower soil
Table 1. Mean values of extractable molybdenum $(\mu \mathrm{g} / \mathrm{g})$ and copper $\mu \mathrm{g} / \mathrm{g})$ in study site soils.

\begin{tabular}{|c|c|c|c|c|}
\hline Soil depth & $\begin{array}{c}\text { Bare } \\
\text { spoils } \\
\# 1\end{array}$ & $\begin{array}{c}\text { Mixed } \\
\text { interburden } \\
\# 2\end{array}$ & $\begin{array}{c}\text { Segregated } \\
\text { interburden } \\
\# 3\end{array}$ & $\begin{array}{c}\text { Native } \\
\text { range } \\
\# 4\end{array}$ \\
\hline \multicolumn{5}{|c|}{ Molybdenum Concentrations } \\
\hline Surface & $.53 \mathrm{aA}^{\prime}$ & $.17 \mathrm{bA}$ & $.17 \mathrm{bA}$ & $.23 \mathrm{bA}$ \\
\hline $20 \mathrm{~cm}$ & $.54 \mathrm{aA}$ & $.19 \mathrm{bA}$ & $.16 \mathrm{bA}$ & $.22 \mathrm{bAB}$ \\
\hline $40 \mathrm{~cm}$ & $.45 \mathrm{aA}$ & $.23 \mathrm{bB}$ & $.24 \mathrm{bA}$ & $.14 \mathrm{bC}$ \\
\hline $80 \mathrm{~cm}$ & $.32 \mathrm{aA}$ & $.28 \mathrm{aB}$ & $.62 \mathrm{bB}$ & $.17 \mathrm{aBC}$ \\
\hline $120 \mathrm{~cm}$ & $.45 \mathrm{aA}$ & $.32 \mathrm{aB}$ & $.46 \mathrm{aB}$ & $.23 \mathrm{aA}$ \\
\hline \multicolumn{5}{|l|}{ overall } \\
\hline Mo means & $.46 \mathrm{a}$ & $.23 \mathrm{ab}$ & $.31 \mathrm{ab}$ & $.19 \mathrm{~b}$ \\
\hline \multicolumn{5}{|c|}{ Copper Concentrations } \\
\hline Surface & $1.2 \mathrm{aA}$ & $0.6 \mathrm{cA}$ & $0.5 \mathrm{cA}$ & $0.8 \mathrm{bAB}$ \\
\hline $20 \mathrm{~cm}$ & $1.4 \mathrm{aA}$ & $0.8 \mathrm{aA}$ & $0.6 \mathrm{aA}$ & $1.1 \mathrm{aA}$ \\
\hline $40 \mathrm{~cm}$ & $1.6 \mathrm{aA}$ & $1.0 \mathrm{abA}$ & $0.5 \mathrm{cA}$ & $0.8 \mathrm{cAB}$ \\
\hline $80 \mathrm{~cm}$ & $1.6 \mathrm{aA}$ & 1.2 bA & $0.3 \mathrm{cB}$ & $0.5 \mathrm{cC}$ \\
\hline $120 \mathrm{~cm}$ & $1.2 \mathrm{aA}$ & $1.9 \mathrm{aA}$ & $0.3 \mathrm{bB}$ & $0.7 \mathrm{bBC}$ \\
\hline \multicolumn{5}{|l|}{ overall } \\
\hline Cu means & $1.4 \mathrm{a}$ & $1.0 \mathrm{~b}$ & $0.5 \mathrm{c}$ & $0.8 \mathrm{~b}$ \\
\hline
\end{tabular}

iMeans followed by same lower-case letter in rows and same capital letter in columns are not different at $p \leq 0.05 \mathrm{~N}=8$ for all depths except $120 \mathrm{~cm}$ where $\mathrm{N}=4, \mathrm{~N}=36$ for overall mean values.

depths which are within the root zone of the legume species and below the $60 \mathrm{~cm}$ of applied topsoil.

Table 1 shows the mean extractable $\mathrm{Cu}$ concentrations for each profile depth and overall mean values for each study site. The topsoiled spoils at Site 3 exhibited a significant $(p \leq 0.5)$ depression in available $\mathrm{Cu}$ at the 80 and $120 \mathrm{~cm}$ depths. This is in sharp contrast to the extractable Mo levels which were elevated in soils from this site at these depths.

\section{Seasonal Variation of Elemental Levels and Ratios}

Plant samples were collected throughout the growing season to evaluate elemental concentrations and subsequent $\mathrm{Cu} / \mathrm{Mo}$ ratios from early growth through senescence.

The single grass species evaluated in this $\mathrm{Cu} /$ Mo uptake study revealed a relatively constant Mo level at each site throughout the growing season. Grass $\mathrm{Cu}$ concentrations decreased at 3 of the 4 sites between spring and fall collections. Alfalfa showed significantly higher levels of Mo in spring samples collected from Sites 2 , 3 , and 4. The other legumes did not demonstrate any change in $\mathrm{Cu}$ or Mo concentrations throughout the growing season or only minor fluctuations at one site. The effects of the few seasonal variations in the elemental status of vegetation on the $\mathrm{Cu} / \mathrm{Mo}$ ratios resulted only in a lower ratio for alfalfa collected in the spring at Site 4 and an elevated ratio for cicer milkvetch in the summer at Site 1.

Since seasonal variations appeared to be relatively unimportant, the data were combined for the 4 sampling periods with mean values for $\mathrm{Cu}, \mathrm{Mo}$, and $\mathrm{S}$ concentrations and $\mathrm{Cu} / \mathrm{Mo}$ ratios exhibited in Table 2. For most species the mean values are based on $\mathrm{N}=12$. The prairieclovers were generally not available for collection in the spring from all plots at all the sites.

\section{Molybdenum Status of Seeded Species}

Most of the legumes from Site 1 demonstrated elevated Mo levels $(p \leq 0.05)$ when compared with the same species grown on the 2 topsoiled mine soil sites or the native range site (Table 2). Legumes grown on the segregated interburden at Site 3 contained higher Mo levels than those grown on the mixed interburden at Site 2, although these differences were not significant. White sweetclover demonstrated the highest mean Mo concentration of all the species at Sites 1,2 , and 3 .

The accumulation of Mo was species specific with white sweetclover and white prairieclover accumulating more of the metal 
Table 2. Mean elemental concentrations and ratios in seeded species.

\begin{tabular}{|c|c|c|c|c|}
\hline Sites & $\begin{array}{c}\text { Bare } \\
\text { spoils } \\
\# 1 \\
\end{array}$ & $\begin{array}{c}\text { Mixed } \\
\text { interburden } \\
\# 2\end{array}$ & $\begin{array}{c}\text { Segregated } \\
\text { interburden } \\
\# 3\end{array}$ & $\begin{array}{c}\text { Native } \\
\text { range } \\
\# 4\end{array}$ \\
\hline \multicolumn{5}{|c|}{ Yellow Sweetclover } \\
\hline $\begin{array}{l}\mathrm{Mo}^{\prime} \\
\mathrm{Cu} \\
\mathrm{S} \\
\mathrm{Cu} / \mathrm{Mo}\end{array}$ & $\begin{array}{l}3.06 \mathrm{a}^{2} \\
7.8 \mathrm{a} \\
0.47 \mathrm{a} \\
3.2 \mathrm{a}\end{array}$ & $\begin{array}{l}1.12 \mathrm{~b} \\
6.9 \mathrm{a} \\
0.28 \mathrm{~b} \\
7.6 \mathrm{~b}\end{array}$ & $\begin{array}{l}1.51 \mathrm{ab} \\
6.5 \mathrm{a} \\
0.37 \mathrm{ab} \\
5.2 \mathrm{ab}\end{array}$ & $\begin{array}{l}0.86 \mathrm{~b} \\
6.4 \mathrm{a} \\
0.31 \mathrm{~b} \\
7.5 \mathrm{~b}\end{array}$ \\
\hline \multicolumn{5}{|c|}{ White Sweetclover } \\
\hline $\begin{array}{l}\text { Mo } \\
\mathrm{Cu} \\
\mathrm{S} \\
\mathrm{Cu} / \mathrm{Mo}\end{array}$ & $\begin{array}{l}5.69 \mathrm{a} \\
8.1 \mathrm{a} \\
0.61 \mathrm{a} \\
1.9 \mathrm{a}\end{array}$ & $\begin{array}{l}1.75 \mathrm{~b} \\
6.2 \mathrm{a} \\
0.29 \mathrm{~b} \\
4.5 \mathrm{a}\end{array}$ & $\begin{array}{l}2.73 \mathrm{~b} \\
6.9 \mathrm{a} \\
0.33 \mathrm{~b} \\
4.0 \mathrm{a}\end{array}$ & $\begin{array}{l}0.75 \mathrm{~b} \\
6.1 \mathrm{a} \\
0.32 \mathrm{~b} \\
9.9 \mathrm{~b}\end{array}$ \\
\hline $\begin{array}{l}\mathrm{Mo} \\
\mathrm{Cu} \\
\mathrm{S} \\
\mathrm{Cu} / \mathrm{Mo}\end{array}$ & $\begin{array}{l}2.17 \mathrm{a} \\
8.4 \mathrm{a} \\
0.50 \mathrm{a} \\
4.4 \mathrm{a}\end{array}$ & $\begin{array}{l}\text { Alfalfa } \\
0.96 \mathrm{~b} \\
6.4 \mathrm{ab} \\
0.27 \mathrm{~b} \\
7.3 \mathrm{ab}\end{array}$ & $\begin{array}{l}1.13 \mathrm{~b} \\
6.7 \mathrm{ab} \\
0.31 \mathrm{~b} \\
7.3 \mathrm{ab}\end{array}$ & $\begin{array}{l}0.67 \mathrm{~b} \\
5.9 \mathrm{~b} \\
0.29 \mathrm{~b} \\
10.3 \mathrm{~b}\end{array}$ \\
\hline \multicolumn{5}{|c|}{ Green Needlegrass } \\
\hline $\begin{array}{l}\text { Mo } \\
\mathrm{Cu} \\
\mathrm{S} \\
\mathrm{Cu} / \mathrm{Mo}\end{array}$ & $\begin{array}{l}0.85 \mathrm{ab} \\
4.2 \mathrm{a} \\
0.21 \mathrm{a} \\
5.5 \mathrm{ab}\end{array}$ & $\begin{array}{l}1.00 \mathrm{a} \\
4.0 \mathrm{a} \\
0.16 \mathrm{ab} \\
4.0 \mathrm{a}\end{array}$ & $\begin{array}{l}0.70 \mathrm{ab} \\
3.5 \mathrm{a} \\
0.15 \mathrm{~b} \\
5.4 \mathrm{ab}\end{array}$ & $\begin{array}{l}0.62 \mathrm{~b} \\
4.1 \mathrm{a} \\
0.17 \mathrm{ab} \\
7.4 \mathrm{~b}\end{array}$ \\
\hline \multicolumn{5}{|c|}{ White Prairieclover } \\
\hline $\begin{array}{l}\text { Mo } \\
\mathrm{Cu} \\
\mathrm{S} \\
\mathrm{Cu} / \mathrm{Mo}\end{array}$ & $\begin{array}{c}4.32 \mathrm{a} \\
10.3 \mathrm{a} \\
0.29 \mathrm{a} \\
2.7 \mathrm{a}\end{array}$ & $\begin{array}{c}0.68 \mathrm{~b} \\
7.0 \mathrm{ab} \\
10.3 \mathrm{~b}\end{array}$ & $\begin{array}{l}1.27 \mathrm{~b} \\
5.9 \mathrm{~b} \\
.26 \mathrm{a} \\
4.9 \mathrm{a}\end{array}$ & $\begin{array}{l}0.62 \mathrm{~b} \\
6.4 \mathrm{~b} \\
11.3 \mathrm{~b}\end{array}$ \\
\hline \multicolumn{5}{|c|}{ Purple Prairieclover } \\
\hline $\begin{array}{l}\text { Mo } \\
\mathrm{Cu} \\
\mathrm{S} \\
\mathrm{Cu} / \mathrm{Mo}\end{array}$ & $\begin{array}{l}3.15 \mathrm{a} \\
7.9 \mathrm{a} \\
0.37 \mathrm{a} \\
3.0 \mathrm{a}\end{array}$ & $\begin{array}{l}0.83 \mathrm{~b} \\
7.7 \mathrm{a} \\
\overline{9.3 \mathrm{~b}}\end{array}$ & $\begin{array}{l}1.02 \mathrm{~b} \\
7.2 \mathrm{a} \\
0.21 \mathrm{~b} \\
9.6 \mathrm{~b}\end{array}$ & $\begin{array}{l}0.57 \mathrm{~b} \\
5.9 \mathrm{a} \\
0.18 \mathrm{~b} \\
11.4 \mathrm{~b}\end{array}$ \\
\hline \multicolumn{5}{|c|}{ Cicer Milkvetch } \\
\hline $\begin{array}{l}\text { Mo } \\
\mathrm{Cu} \\
\mathrm{S} \\
\mathrm{Cu} / \mathrm{Mo}\end{array}$ & $\begin{array}{l}2.23 \mathrm{a} \\
7.2 \mathrm{a} \\
0.47 \mathrm{a} \\
4.3 \mathrm{a}\end{array}$ & $\begin{array}{l}0.76 \mathrm{~b} \\
5.5 \mathrm{a} \\
0.26 \mathrm{~b} \\
7.4 \mathrm{~b}\end{array}$ & $\begin{array}{l}0.92 \mathrm{~b} \\
6.2 \mathrm{a} \\
0.27 \mathrm{~b} \\
8.1 \mathrm{~b}\end{array}$ & $\begin{array}{l}0.83 \mathrm{~b} \\
5.8 \mathrm{a} \\
0.27 \mathrm{~b} \\
8.9 \mathrm{~b}\end{array}$ \\
\hline
\end{tabular}

'Mo and $\mathrm{Cu}$ concentrations in $\mu \mathrm{g} / \mathrm{g}, \mathrm{S}$ in $\%$.

${ }^{2}$ Means followed by same letter in rows are not different at $p \leq 0.05$. $\mathrm{N}=12$ for most means; $N$ varies from 6 to 10 for prairieclover mean values.

$3(-)$ indicates insufficient sample for analysis.

than the other legumes. Uptake of Mo was also site specific with the plants containing elevated levels of $\mathrm{Mo}$ in soils of higher extractable concentration. These findings are in agreement with Allaway (1977) who found that different plant species accumulated substantially different amounts of Mo from the same soil or culture, with leguminous vegetation containing more of the metal than grasses in the same area.

\section{Copper Status of Seeded Species}

Table 2 lists $\mathrm{Cu}$ concentrations in the 6 legumes and 1 grass species. The data indicate that vegetation grown at Site 1 contained the highest levels of $\mathrm{Cu}$ with alfalfa and white prairieclover concentrations being elevated ( $p \leq 0.05$ ). Green needlegrass, cicer milkvetch, purple prairieclover, and both sweetclovers exhibited no variation in $\mathrm{Cu}$ levels among the $\mathbf{4}$ study areas. The $\mathrm{Cu}$ status of the vegetation appeared to be species specific, but not site specific. Only some species accumulated higher levels of $\mathrm{Cu}$ when grown on soil containing more available $\mathrm{Cu}$.

Levels of this metal in vegetation grown on native range soils were statistically equivalent to levels of $\mathrm{Cu}$ in vegetation from the 2 topsoiled sites. Other studies (Kubota et al. 1967, Kubota 1975) have also confirmed that plants of the same species with widely different Mo concentrations may have similar levels of $\mathrm{Cu}$.

\section{Copper:Molybdenum Ratios in Seeded Species}

Legume species from Site 1 revealed lower $\mathrm{Cu} / \mathrm{Mo}$ ratios than the same vegetation grown on the native range study site (Table 2). White sweetclover from Site 1 had a mean ratio below the critical dietary ratio for cattle of 2.0. Vegetation grown on the two topsoiled sites exhibited similar $\mathrm{Cu} /$ Mo ratios except for white prairieclover. The mean ratios of all species at Sites 2, 3, and 4 were well above the critical dietary value with vegetation grown on the native soil displaying the highest ratios.

\section{Sulfur Status of Seeded Species}

High levels of dietary $\mathrm{S}$ and Mo restrict $\mathrm{Cu}$ utilization by depressing its solubility in the digestive tract through the precipitation of insoluble copper thiomolybdate, $\mathrm{CuMoS}_{4}$ (Dick et al. 1975). Suttle (1975) demonstrated that total S rather than inorganic $S$ is the more useful measurement in evaluating the $\mathrm{Cu}-\mathrm{Mo}-\mathrm{S}$ interrelationship.

Most legumes grown on Site 1 exhibited elevated S levels $(p \leq 0.05)$ compared with vegetation from the other sites (Table 2). White sweetclover from Site 1 showed the highest mean $\mathrm{S}$ level $(0.61 \%)$ and green needlegrass from Site 3 exhibited the lowest $S$ concentration (0.15\%). Martin and Matocha (1973) summarized the $\mathbf{S}$ status of alfalfa and described deficient, critical, adequate, and high nutrient concentrations. This species was considered $\mathbf{S}$ critical at $<0.20-0.35 \%$, adequate at $0.26-0.50 \%$, and high at levels greater than $0.51 . \%$. In comparison to alfalfa, legumes in this mine soil study appear to be within low-normal limits for adequate vegetation $S$ nutrition.

Limits of S concentration associated with disturbed $\mathrm{Cu}$ metabolism in animals have not been well defined in the literature. However, several investigators have indicated that levels above $0.35 \%$ are generally found in relation to abnormal $\mathrm{Cu}$ metabolism (Spais 1959, Whitehead and Jones 1969, Havre and Dishington 1962). Mean S concentrations in the legumes from Sites 2, 3, and 4 are below this level, while those from Site 1 exceed $0.35 \%$ (Table 2 ).

Table 3. Vegetation showing acceptable molybdenum concentrations and ratios when grown on each study site.

\begin{tabular}{lccc}
\hline Vegetation species & $\begin{array}{c}\text { Acceptable Mo content } \\
(90 \% \text { of samples }<5.0 \mu \mathrm{g} / \mathrm{g})\end{array}$ & $\begin{array}{c}\text { Acceptable Cu:Mo ratio } \\
(90 \% \text { of samples }>2.0)\end{array}$ & $\begin{array}{c}\text { Overall acceptability } \\
\text { of vegetation }\end{array}$ \\
\hline & \multicolumn{1}{c}{ Sites } & $\frac{\text { Sites }}{234}$ & \multicolumn{2}{c}{$\begin{array}{c}\text { Sites } \\
\text { Yellow sweetclover }\end{array}$} \\
White sweetclover & 1234 & 234 & 4 \\
Alfalfa & 234 & 1234 & 1234 \\
Green needlegrass & 1234 & 1234 & 1234 \\
White prairie clover & 1234 & 234 & 234 \\
Cicer milkvetch & 234 & 1234 & 1234 \\
Purple prairieclover & 1234 & 234 & 234 \\
\hline
\end{tabular}




\section{Summary and Conclusions}

Statistical differences between specific parameters at Site 1 (no topsoil), Site 2 (mixed interburden and overburden) and Site 3 (segregated interburden) were of prime importance. These parameters included differences in extractable Mo within the plant root zones, differences in $\mathrm{Cu}$ and Mo levels in the seeded species, and differences in vegetation $\mathrm{Cu} /$ Mo ratios.

Extractable soil Mo concentrations in the topsoil applied at Sites 2 and 3 were similar. All species grown on the two topsoiled areas exhibited mean Mo levels below critical dietary concentrations for grazing cattle of $5 \mu \mathrm{g} / \mathrm{g}$.

The uptake of Mo by the legumes was species and site specific. All of the legumes accumulated higher levels of Mo when grown on soils with increasing extractable Mo concentration.

Table 3 shows which of the seeded species evaluated may be planted on different sites and meet acceptable Mo levels and $\mathrm{Cu} / \mathrm{Mo}$ ratios for grazing cattle. Acceptable performance was based upon 2 factors: $90 \%$ of the samples of any species must reveal Mo concentrations below $5 \mu \mathrm{g} / \mathrm{g}$ and $\mathrm{Cu} /$ Mo ratios must be greater than 2.0. Based on these criteria, 4 of the legumes should not be seeded on bare spoils of Site 1 .

With the exception of white sweetclover, the legumes grown on the 2 topsoiled mine soils exhibited mean $\mathrm{Cu}, \mathrm{Mo}$, and $\mathrm{S}$ levels and $\mathrm{Cu} / \mathrm{Mo}$ ratios within normal dietary limits for grazing cattle and were not statistically distinct. They could safely be seeded and consumed by livestock on these topsoiled mine soils.

Since leguminous species would not constitute the sole diet of grazing animals, the intake of Mo in the total diet would not be as high as levels provided by these legumes alone. The subsequent dietary $\mathrm{Cu} / \mathrm{Mo}$ ratio of free ranging livestock or wildlife would probably be higher than values reported in this study.

Mixing or dilution of the Mo bearing shale interburden located between the Rosebud and McKay coal seams at the Big Sky Mine with sandy overburden in the reclamation process did not result in undesirable Mo levels or $\mathrm{Cu} / \mathrm{Mo}$ ratios in the legumes evaluated as long as the site was covered with an adequate depth of suitable topsoil.

\section{Literature Cited}

Allaway, W.H. 1977. Perspective on molybdenum in soils and plants. p. 317-339. In: W.R. Chappell and K.K. Petersen (Eds.), Molybdenum in the Environment. Marcel Dekker, Inc. N.Y.

Barshad, I. 1948. Molybdenum content of pasture plants in relation to toxicity to cattle. Soil Sci. 66:187-195.

Dick, A.T., D.W. Dewey, and J.W. Gawthome. 1975. Thiomolybates and the copper-molybdenum-sulphur interaction in ruminant nutrition. J. Agr. Sci., Camb. 85:567-568.
Erdman, J.A., R.J. Ebens, and A.A. Case. 1978. Molybdenosis: A potential problem in ruminants grazing on coal mine spoils. J. Range Manage. 31:34-36.

Ferguson, W.S., A.H. Lewis, and S.J. Watson. 1943. The teart pastures of Somerset: I. The cause and cure of teartness. J. Agr. Sci. 33:45-51.

Havre, G.N., I.W. Dishington. 1962. The mineral composition of pasture as influenced by various types of heavy nitrogen dressings. Acta. Agr. Scand. 12:298-308.

Horwitz, W. (Ed.). 1975. Official Methods of Analysis of the Association of Official Analytical Chemists. 12th Ed. Method. 3-059. Assoc. Off. Anal. Chem. Washington, D.C.

Kubota, Joe. 1975. Areas of molybdenum toxicity to grazing animals in the western states. J. Range Manage. 28:252-256.

Kubota, Joe, V.A. Lazar, G.H. Simonson, and W.W. Hill. 1967. The relationship of soils to molybdenum toxicity in grazing animals in Oregon. Soil Sci. Amer. Proc. 31:667-671.

Martin, W.E., and J.E. Matocha. 1973. Plant analysis as an aid in the fertilization of forage crops. In: Walsh, L.M. and J.D. Beaton (Eds.). Soil Testing and Plant Analysis. Soil Sci. Soc. Amer. Madison, Wis.

Miltimore, J.E. and J.L. Mason. 1971. Copper and molybdenum ratio and molybdenum and copper concentrations in ruminant feeds. Can. $J$. Anim. Sci. 51:193-200.

Munshower, F.F. and D.R. Neuman. 1978a. Trace element concentrations in vegetation from revegetated strip mined land and native range in southeastern Montana. p. 887-891. In: M.K. Wali (Ed.). Ecology and Coal Resource Development, Vol. 2, Pergamon Press, New York.

Munshower, F.F., and D.R. Neuman. 1978b. Elemental concentrations in native range grasses from the Northern Great Plains of Montana. J. Range Manage. 31:145-148.

Munshower, F.F., and D.R. Neuman. 1980. Elemental concentrations in native plant species growing on minesoil and native range. Reclamation Review. 3:41-46.

National Research Council, Subcommittee on Beef Cattle Nutrition. 1976. Nutrient requirements of beef cattle. Printing and Publishing Office, Nat. Acad. Sci., Washington, D.C.

National Research Council, Subcommittee on Dairy Cattle Nutrition. 1971. Nutrient requirements of dairy cattle. Printing and Publishing Office, Nat. Acad. Sci., Washington, D.C.

Neuman, D.R., and F.F. Munshower. 1981. Rapid determination of molybdenum in botanical material by electrothermal atomic absorption spectrometry. Anal. Chim. Acta. 123:325-328.

Spais, A.G. 1959. Le cuivre en pathologie ovine et bovine. Rec. Med. Vet. 135:161-194.

Sullivan, J.T. 1969. Chemical composition of forages with reference to the needs of grazing animals. Agr. Res. Serv. Rep. No. 34-107. USDA, Washington, D.C.

Suttle, N.F. 1975. The role of organic sulfur in the copper-molybdenum-S relationship in ruminant nutrition. Br. J. Nutr. 34:411-420.

Underwood, E.F. 1977. Molybdenum in animal nutrition. p. 9-32. In: W.R. Chappell and K.K. Petersen (Eds.). Molybdenum in the Environment. Marcel Dekker, Inc., N.Y.

Webb, J.S., and W.J. Atkinson. 1965. Regional geochemical reconnaissance applied to some agricultural problems in Co. Limerick. Eire. Nature 208:1056-1059.

Whitehead, D.C., and E.C. Jones. 1969. Nutrient elements in the herbage of white clover, red clover, lucerne and sainfoin. J. Sci. Food Agr. 20:584-591. 